\title{
MOTHER'S PERSPECTIVE OF MAINTAINING AN ACTIVE OUTDOOR LEISURE TIME FOR A PRESCHOOL CHILD
}

\author{
Saša PIŠOT ${ }^{1}$ \\ ${ }^{1}$ Science and Research Centre, Koper, Slovenia \\ Corresponding Author: \\ Saša PIŠOT \\ Science and Research Centre, Koper, Institute for Kinesiology Research, \\ Garibaldijeva 1, SI-6000 Koper, Slovenia \\ Phone: +3866637731 \\ E-mail: sasa.pisot@zrs-kp.si
}

\section{ABSTRACT}

In the contemporary life of a family, mothers are often faced with a conflict between work and family in order to assure a healthy childhood for their children. How to provide active leisure time for a child in accordance with healthy lifestyle guidelines, and what factors affecting the quantity and quality of a child's physical activity, have been researched from the perspective of mothers. The qualitative and quantitative methods of questionnaires and semi-structured interviews $(n=54)$ with mothers were executed with the aim to study important factors which distract mothers and their children from ensuring physically active leisure time. Additionally, the possible correlation of children's motor efficiency and family characteristics were studied. From the mother's perspective we found that "lack of time" along with "weather conditions" were two major obstacles. Mothers also indicated "the access to recreational facilities" and "health of a child" as common impetuses for active outdoor leisure time. Additionally, comparison of family characteristics showed that active family leisure behavior is influenced by i) demographic and personal factors of the family (family size, SES, sports history), ii) social factors (employment and schedule of employment, financial status of the family, social networks support), and iii) environmental factors (weather, accessibility, and safe conditions for physical activity, as well as living conditions). Because environmental factors are harder to change, we need to pay attention to demographic, personal, and social factors of mothers (families) with reduced possibilities and enable them to ensure conditions for healthy child development.

Keywords: physical activity, family's leisure time behavior, personal and social factors of $P A$, motor efficiency. 


\section{USKLAJEVANJE AKTIVNEGA PREŽIVLJANJA PROSTEGA ČASA PREDŠOLSKIH OTROK IZ PERSPEKTIVE MATER}

\section{IZVLE ČEK}

Sodobno življenje družine s predšolskimi otroki postavlja predvsem pred matere dnevne izzive. Zagotoviti otrokom kvalitetno preživljanje prostega časa v obliki gibalnih/športnih aktivnosti na prostem, ob delovnih obveznosti nemalokrat privede do konflikta med delom in družino. Kako skladno s smernicami zdravega življenjskega sloga nuditi otroku dovolj gibanja in aktivno preživljanje prostega časa, predvsem kateri so najpogostejši dejavniki, ki vplivajo na količino in kvaliteto gibalne aktivnosti, smo proučevali na primeru mater predšolskih otrok, ki še vedno ohranjajo primarno vlogo nosilk skrbi za otroke. Izvedli smo vprašalnike ter polstrurkturirane intervjuje $(n=54)$ ter preko sinteze kvalitativnih in kvantitativnih metod nadalje ugotavljali povezanost med otrokovo motorično učinkovitostjo, značilnostmi preživljanja prostega časa ter socio-demografskimi značilnostmi družine. Ugotovili smo, da je pomanjkanje časa, poleg slabih vremenskih razmer ena izmed glavnih ovir za vsakodnevno gibalno aktivno preživljanje časa na prostem. Matere so kot vzrok navedle tudi slabši dostop do površin in navadno slabše zdravstveno stanje otroka. V nadaljnji primerjavi gibalne učinkovitostjo otroka in aktivnega preživljanja časa na prostem ugotavljamo tudi vpliv i) demografskih in osebnih dejavnikov družine (število družinskih članov, zdravstveni status, športna zgodovina staršev), socio-ekonomskim dejavnikov (zaposlitveni status staršev in delovna obremenitev, finančni status ter socialna mreža pomoči) ter okoljski dejavniki (vremenski pogoji, dostopne in varne zunanje površine, bivanjski pogoji), ki pa se spreminjajo $v$ času. Na določene fizične in okoljske dejavnike je težje vplivati, zato je učinkoviteje, da pri reševanju pozornost namenimo demografskim, osebnim in socio-ekonomskim dejavnikom ogroženih mater oz. družin (nizki dohodki, enostarševske družine) in omogočimo boljše pogoje za aktivno preživljanje prostega časa.

Ključne besede: gibalna/športna aktivnost, družinski vzorci preživljanja prostega časa; osebni, socialni in okoljski dejavniki G $\breve{S} A$, motorična učinkovitost. 


\section{INTRODUCTION}

Today's contemporary family is facing the problem of time management, balancing between work and leisure time with family members. The labor market, especially since the late 1970s, has provided more and more employed women. Even though this development can be characterized as a major success of emancipation and many economies derived great benefits from the additional labor supply and the contribution of women (OECD, 2001), this advance toward equality in the labor market paradoxically means that women become active in two domains of life: their traditional domain of care of the family members, along with that of work (Bettio et al., 2014). This new status often ends in Work-Family Conflict (WFC), (Lewis \& Lewis, 1996) which is primarily a matter of limited time available (Remery \& Schippers, 2019). Sometimes the total work and family tasks may exceed the available time budget ( 24 hours/day) and work and family tasks require parents to be in different places at the same time, so WFC may develop from intertemporal problems. Alongside the contemporary phenomena of "intensive" parenting, "child centricity" and "protective" childhood still indicate an emphasis on intense maternity as an exclusive, fully child-centric, emotional and long-term mandate (Pišot, 2018; Arunel et al., 2019). Despite "active" fatherhood, we are also witnessing in gender-work related equality in Slovenia, that the father's role is treated more as parental support in the play and engaging in sports with children (Rener et al., 2008), while the household remains in the domain of mothers (Rener, 2006). Contrary to the evident WFC, resent research has pointed out the problem that children are not physically active enough; i.e., becoming more sedentary, especially in their adolescence. The increase of screen time clearly reduces time spent physically active, and results in altered development of motor patterns, which have changed remarkably in recent decades, especially free outdoor play, as traditional games are replaced by several indoor more sedentary games (computer games). This pandemic of sitting (Andersen, Mota \& Di Pietro, 2016) exists along with the widely spread paradigm of positive health benefits of physically active lifestyles that can diminish health risk factors (cholesterol, depression, injury, bone density, blood pressure, obesity, metabolic syndrome) (Janssen \& LeBlanc, 2010). Regular physical activity (PA) in childhood is necessary to establish elementary motor patterns needed for children's physiological, motor, and psychological development (Owen et al., 2010; Dietz, 1998; Biddle \& Asare, 2011; Mutrie \& Parfitt, 1998). Particularly for children and adolescents, early physical activity experiences are important for influencing active lifestyles in their adulthood (Thompson, Humbert, \& Mirwald, 2003). Furthermore, childhood is considered the best time for the socialization of children into physically active leisure time because of the development of motor competence (physical activity skills), attitudes, values, and behaviors (Telama, Yang, Laakso, \& Viikari, 1997). Unfortunately, being active in leisure time with all its benefits is becoming a challenge for the contemporary family. Arising from the age and contexts of preschool children, busy daily schedules no longer favor families depending on many factors, including the socioeconomic status 
of the family and their "time free from economic necessity" (Bourdieu in Kamin \& Tivadar, 2011). When family leisure time is shrinking, additional efforts should be made to encourage and enable physically active leisure time of families. Previous longitudinal studies (Bouchard, 1996) showed that parents had a significant role in support (e.g., financial, practical, and emotional) and were role models for physically active leisure. In fact, one study noted that children of active parents were 5.8 times more likely to be active in their adulthood than children of inactive parents (Bouchard, 1996). Lack of parental support, on the other hand, negatively influenced attitudes and behaviors towards physically active leisure during childhood and adolescence with a lasting effect in adult years. In general, the parental support showed facilitated involvement and the more support was perceived, the more the level of physically active leisure increased either directly or indirectly through its influence on a child's efficacy (Trost et al., 2003).

The determinants of a physically active lifestyle are complex and are mostly socio-demographic (sex, age, socioeconomic status, ethnicity, presence of mother/ father in household, work status) and environmental correlates of physical activity (urban residence, use of community recreation facilities, crime in neighborhood, region) (Gordon-Larsen, McMurray, \& Popkin, 2000). While socio-cultural factors are most often associated with physical activity, socio-demographic factors relate more to sedentary leisure time. Environmental (physical) factors such as living environment of a family (home, neighborhood, facilities for PA) and the living conditions from the point of view of accessibility and safety significantly influence families (Dowda et al., 2011; Kerr et al., 2006; Saelens, Sallis, Black, \& Chen, 2003).

Despite the important role of environmental and socio-cultural factors where parents are key to primary socialization, little is known about the mothers' perspective and strategies regarding their children's PA in leisure time. Little research has particularly been undertaken to understand the choices and opportunities of mothers to ensure children's healthy lifestyle regarding active outdoor leisure time, particularly from their perspective and in a format that allows them to reflect on their individual experiences (Thompson et al., 2003). Our research question refers to mothers facing the WFC in enhancing healthy family lifestyle and outdoor physical activity of children in leisure time. The study includes mothers of preschool children in regard to perceived barriers which enable or inhibit them to go out and ensure their children are physically active in their leisure time. Additional research referred to other factors that influence family active leisure behavior: i) demographic and personal factors of the family (family size, health status, sports history), ii) social factors (employment and work shift, financial status of the family, social networks support), and iii) environmental factors (weather, accessibility, availability and safe conditions for physical activity, or family living conditions) impacting the motor efficiency (ME) of a child (measured as elementary motor patterns assignments and summed as motor efficiency).

1 "Time free from economic necessity" refers to time free of work or activity that enables provision for necessary means for living (Bourdieu, 1986). 


\section{METHODS}

A mixed method approach was used including the qualitative (a part of semi-structured interview concerning family lifestyle) and quantitative approach (questionnaires' data and quantitative grouping of children according to their motor efficiency test results). That kind of method enabled us to study the problems of enhancing a healthy family lifestyle from the mother's perspective:

a. from the scope of the extent of perceived barriers which enable or inhibit outdoor physical activity of children during leisure time;

b. from the qualitative view of the factors influencing a mother's parenting in the domain of active outdoor leisure time;

c. from the perspective of qualitative comparison of links between demographic, socio-economic, and environmental factors of the family and the child's motor performance (efficiency).

The research sample: The research was conducted in the frame of the national applied project "Analyses of Elementary Motor Pattern, Skeletal and Muscular Adaptation on Specific Sedentary Lifestyle Factors amongst 4 to 7 Year Old Children.” The semi-structured interviews $(n=60)$ and questionnaires $(n=87)$ investigating a family's everyday life were carried out with mothers of four-year-old children involved in the project $(n=107)$. For the study we obtained data from a specific sample involving mothers who carried out the interview $(n=54)$, filled in the questionnaires $(n=54)$, and allowed the participation of their four-year-old children in the motor efficiency measurements $(\mathrm{N}=54$, boys $=26)$. The interviews were executed from April to August 2010, along with questionnaires, which asked mothers to list the most significant factors enabling them and other family members to be physically active outdoors during their leisure time.

Questionnaires regarding demographic and family lifestyle characteristics were conducted as a part of the introduction to the semi-structured interview (written consent of participation by parents). Specific questions in the questionnaire referred to the insights about perceived factors influencing PA or active outdoor leisure time of a child in the domains of i) time management (lack of time for PA because of other, more important, tasks); ii) personal factors (mother's and child's health status or well-being), iii) social factors (low financial or material status), and iv) physical and environmental factors (limited accessibility to sports facilities, low physical-environmental possibilities to execute PA and disadvantageous weather conditions).

The interviews mostly took places in families' homes or favorite places (quiet cafés, coffee shops and patisseries with gardens, etc.) and were transcribed from the recordings. The average time of the interview was 20.3 minutes ( \pm 6.22 minutes). Topics of the semi-structured interviews were related to: i) family everyday life and the spending of leisure time together, including on weekends and during holidays (description of the typical day during the week, weekend and holidays); ii) implementation of the health-oriented practices in the family (nutrition, physical activity, hygiene) as an insight into the replication of the imperatives of "intensive maternity"; 
iii) parental support (information on the support that parents provide their children in physical activity); iv) retrospective of parents' childhood - with focus on PA as determinants of a healthy lifestyle. Data were thematically coded to identify convergences according to the research topic. For the purpose of the research question, we analyzed only the first topic regarding the families' everyday lives in the domain of leisure time (afternoon, weekends and holidays).

Data analysis - Quantitative data from the questionnaire were analyzed with the statistical program IMB SPSS, version 24, and descriptive analysis were carried out. Additionally, the frequency analyses and means (z-values) of elementary motor patterns assignments ${ }^{2}$ was added as motor efficiency (ME) and the sample of children was divided into four groups: the group of the most motor efficient children - group 1 (G1), two groups of children with average motor efficiency - group 2 (G2) and 3 (G3), and the group of children with lowest motor efficiency - group 4 (G4). The analysis of mean values and frequency distributions of individual variables within groups (using the descriptive method), the One-way ANOVA test, and an additional post hoc test were performed for all four groups separately.

Table 1 Groups: children divided regarding the level of motor efficiency.

\begin{tabular}{|c|c|c|c|c|c|c|c|c|c|c|}
\hline & n & $\%$ & $\begin{array}{c}\text { Group 1 } \\
(\mathbf{G 1})\end{array}$ & $\%$ & $\begin{array}{c}\text { Group 2 } \\
(\mathbf{G 2})\end{array}$ & $\%$ & $\begin{array}{c}\text { Group 3 } \\
(\mathbf{G 3})\end{array}$ & $\begin{array}{c}\text { Group 4 } \\
(\mathbf{G 4})\end{array}$ & $\%$ \\
\hline Boys & 26 & 48.1 & 7 & 70 & 5 & 45.5 & 5 & 33.3 & 9 & 50 \\
\hline Girls & 28 & 51.9 & 3 & 30 & 6 & 54.5 & 10 & 66.7 & 9 & 50 \\
\hline Total & 54 & 100 & 10 & 100 & 11 & 100.0 & 15 & 100.0 & 18 & 100 \\
\hline
\end{tabular}

2 For the monitoring of Elemental Movement Patterns (EGVs) and motor skills several test batteries are used (Movement assessment Battery for Children (Sugden \& Henderson et al., 2007); Gross Motor Development Test (Ulrich, 2000); Bruininks-Oseretsky Motor Proficiency Test (Bruininks \& Bruininks, 2005) and others. Due to the specific and complex objectives in the project the Institute for Kinesiology Research prepared its own battery of motion tests and validated the scale of the conformity assessment of the EGV implementation. This was based on qualitative and quantitative analysis and performance evaluation and consisted of 9 different tests: quantitative and qualitative parameters of walking and running, climbing and crawling, and a counter movement jump on a tensiometer plate. 


\section{RESULTS}

Results from the questionnaire showed reasons for the distraction or inhibition on the part of mothers from spending active leisure outdoor time with their children were: weather conditions $(27.8 \%)$ and lack of time $(27.8 \%)$, followed by spatial conditions (16.7\%) and limited accessibility to sports facilities (16.7\%); and less frequently cited were the mother's and child's current well-being (13.0\%). Finances and general mother's health status $(7.4 \%)$ were not shown as a limiting factor, while general child's health status $(5.6 \%)$ had the lowest impact from the mother's perspective (see Figure 1).

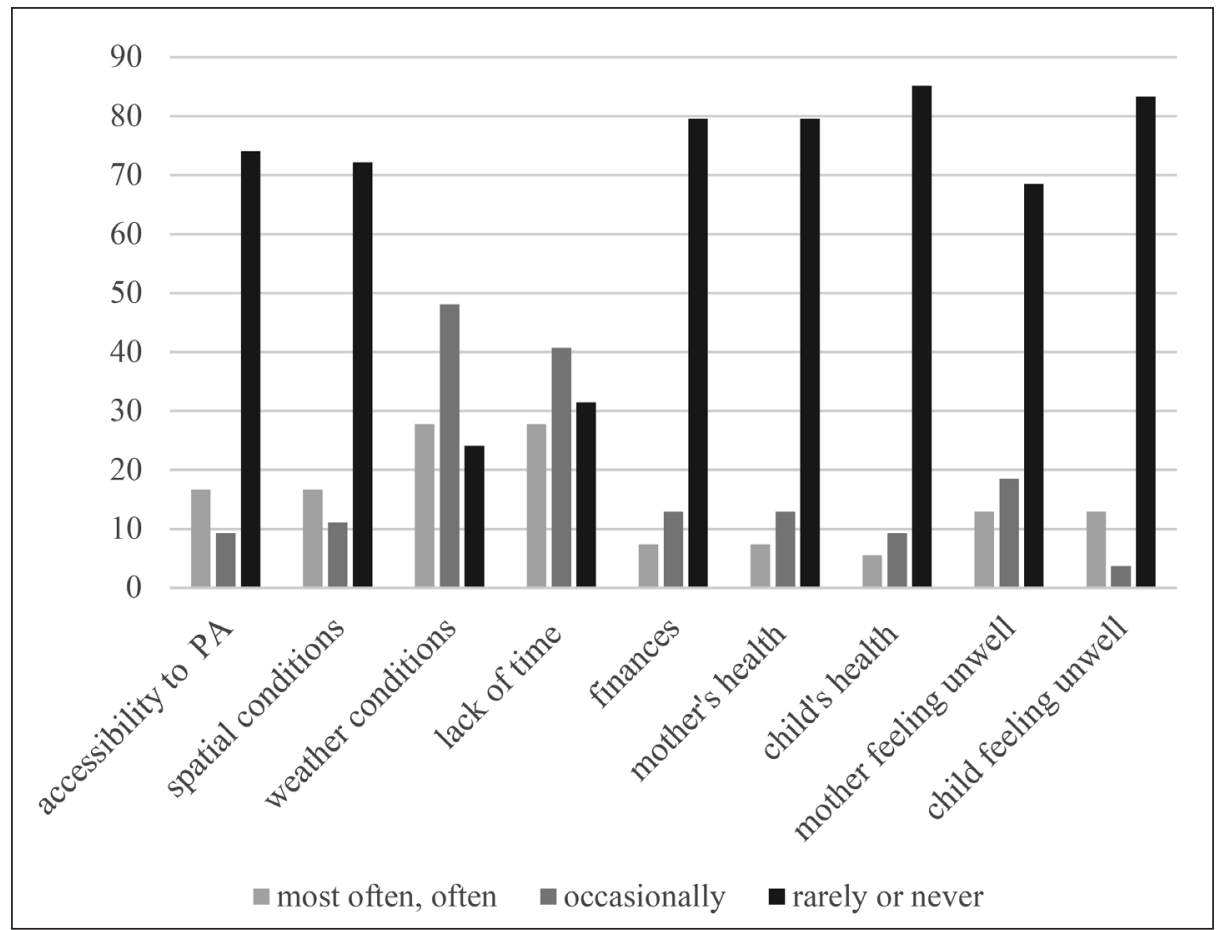

Figure 1: Factors of distracting mothers from spending active outdoor leisure with a child.

The "lack of time" as one of the most common reasons was mentioned in mothers' statements from the semi-structured interviews and reflected the perception of lack of time as an imperative of the work-family conflict. 
“... / Even in the afternoons, the days are so short ... There's no time; there's no 'me time, 'of course, but there's not even enough time to be spent with the child." (mother of a boy from G4, 29 years, secondary education)

"Weekends are the worst, as there are various household chores breaking up the day ... like tidying up, cleaning, other things /... / I'd like to go on a day trip to see something. You know, to have Sundays to ourselves and spend them actively, now that they (children - author's note) are bigger, by bike or maybe to go on a hike." (mother of a boy from G4, 37 years, higher education diploma)

There was an interesting answer that one mother gave to the question what she would do if she could:

“... If I could make a choice, I would be a homemaker, take my child to kindergarten, then clean the house and make lunch and pick him (the child - author's note) up from the kindergarten. Then I would smile all afternoon. Yes, if I could make that choice, I would be like that /.../ If I had two hours in the afternoon, I would go with my child for a walk with no hurry. /.../ My 'dream' weekend, yes (laughs), a housekeeper who cleaned everything for me ... it would be nice to find everything cleaned when you return home from a trip or outdoor activities." (mother of a boy from G4, 43 years, secondary education).

Additionally, questionnaire data were compared with children's motor efficiency by dividing the sample into four groups (G1, G2, G3, G4) and additional frequency analyses. Assuming that the differences of distracting factors will be shown between most motor efficient and less motor efficient children, we compared answers of mothers of children in groups G1 $(n=10)$ and G4 $(n=18)$. The analysis was made despite the differences in the number of children, since families' characteristics showed no statistical differences between both groups.

Data showed that "lack of time" was higher in G4 (38.9\%, i.e., 7 mothers) than in G1 (20\%, i.e., only 2 mothers). "Spatial conditions for active outdoor PA" was also a higher factor in G4 (22.2 \%, i.e., 4 mothers) in comparison to G1 (10 \%, i.e., only 1 mother), while "weather conditions" were comparable in both groups G1 (30 $\%$, i.e., 3 mothers) and G4 (22\%, i.e., 4 mothers). Interestingly, mothers of the most efficient children reported higher percentages of mothers and children momentarily feeling unwell (G1 $20 \%$ vs. G4 5.6 \%, and G1 $30 \%$ vs. G4 5.6\%) as a factor for not spending active outdoor leisure time. Despite the fact that finances were not the main factor, $11.2 \%$ or 3 mothers from G4 still named financial means as a reason why they were not active outdoors, while in G1 this was not mentioned (see Figure 2).

Further analyses of questionnaire data in the domain of family characteristics confirmed that living conditions of families could have an impact on spending active outdoor leisure time. Environmental factors are cited as important determinants of the amount of PA (Sallis et al., 2000; Hayley et al., 2017); therefore the living condi- 

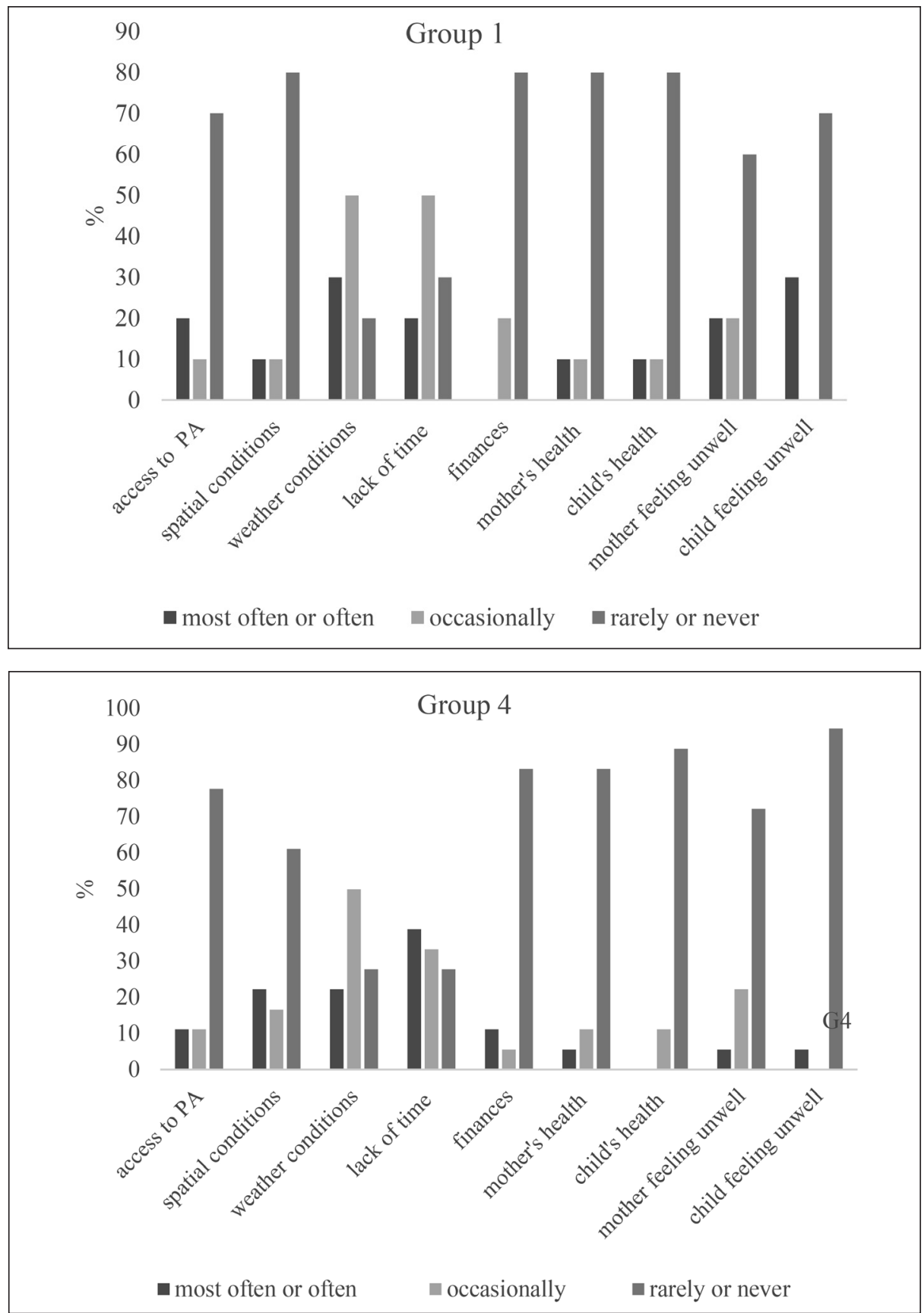

Figure 2: Factors of active outdoor leisure of children from G1 and G4. 
tions of the families were investigated. We found some important differences where more motor efficient children mostly lived in a house with a yard $(2 / 3$ of children of G1) in suburbs or villages, while $50 \%$ of less motor efficient children (G4) lived in a block of flats in towns, where free outdoor play is limited.

“... In the afternoons, I pick her (daughter - author's note) up from the kindergarten and then it depends: if the weather is nice, we stay a little longer in the kindergarten courtyard, where the girl swings, climbs the houses, or we wait for another friend to go home together. I prepare lunch at home while my daughter stays outside in the yard or plays in the house. When Dad comes from work, we eat lunch together and then decide what we will do in the afternoon, whether we will go out or just stay at home, depending on the day." (mother of a girl from G1, 31 years, secondary education)

However, mothers of children from G4 reported fewer outdoor possibilities as "the place where a child mostly spent his/her leisure time" in $44.4 \%$ was the garden or house yard (vs. G1 $80 \%$ ) and playground (G4 22.2 \% vs. G1 $20 \%$ ). Additionally, children from G4 also combined playground or house yard with indoor play in apartment or room (22.2\%), with the exception of a boy from G4 who mostly spent his leisure time in his room.

An additional look at family socio-demographic characteristics could explain the possible impact of spending family leisure in connection to the level of child motor efficiency. The gender difference among the group G1 and G4 was in favor of boys in the most motor efficient (G1 $60 \%$ ) and the less motor efficient group (G4) to girls $(57 \%)$, which could be explained by physiological characteristics of the child's development. Besides that, it also confirmed the role sport plays in a society where boys are more encouraged to engage in sports and other physical activities. The mean body mass index (BMI) of children from G1 and G4, as well as in other groups (G2 and G3) did not differ $(p=0.202)$. Interestingly, from the point of family characteristics, in a group of the most efficient children (G1) there were more children coming from "small" families with one or two children, or only children (40\%). Further, 2/3rds of them were first-borns, while a greater share of second-born children from families with more children ( $55 \%$ ) were found in G4. This could be explained as caused by the impact of increased parental attention given to the single or first-born child due to the phenomenon of "intensive parenting."

We compared demographic and SES characteristics of parents of children from G1 and G4 to assess their possible influence on spending leisure time. There were no significant differences in age between the groups: fathers' mean age was $33.8 \pm$ 4.6 years, while the average mothers' age was $35.7 \pm 5.18$ years. Secondary education and vocational education were dominant in all groups, also reflected in the parent's classification of their family in the middle class (G4 $75 \%$ vs. G1 46\%) and in the upper middle class (G4 $15 \%$ vs. G1 $45 \%$ ). From the aspect of family income (per family member) we also found lower income for families of children from G4 (33\%) 
with less than $€ 500 /$ member/month, while all other groups reported income between $€ 801$ and $€ 1,500$ per member, indicating a lower economic status for G4. That could be explained by a higher proportion of unemployed parents in G4 (15\%) leading to fewer resources and possibilities for more active leisure time. Low financial and material status as an obstacle to not spending active weekends and holidays were also reported.

"Winter and summer holidays are practically like weekends, we stay at home, well, sometimes we go somewhere for a day. In the summer, though, yes, my daughter and I are going to the beach alone. Since our daughter was born we haven't been on holidays yet. Yes, it would be ideal for me to go on holidays, now this is primarily impossible because of finances and my husband's work." (mother of a girl from G4, 41 years, secondary education)

From the point of family support to child's PA, interviews showed that mothers are the main motivators $(2 / 3)$ for a child to learn a new sport (rollerblading, cycling, skiing, swimming), but in most cases, especially when they do not have their own sports history, they leave the teaching of new sports to the fathers $(60 \%)$ or professionals.

"... Otherwise, the initiative comes from me because I spend more time with the children, usually the father comes along and also the older sister, and then we agree on how we will carry it out [...], e.g., when skiing, we both tried to do it and then we saw that it was best if experts do it and we enrolled him in ski school [...]. It went faster. (mother of a boy from G1, 37 years, college degree)

\section{DISCUSSION}

Mothers' spending active outdoor leisure time with children is closely connected with family characteristics and possibilities (personal, social, and environmental factors) to overcome the most commonly noted barriers that distract them from engaging in active outdoor leisure time with a child. Qualitative and quantitative data analysis of the presented sample showed that being a girl, coming from a family with more siblings, living in a flat in the city, occasionally feeling unwell or tired, with a mother who works two shifts, a father who is working late and sometimes on weekends, with parents without a sports history, a weak social network (relatives support), and low financial status, all are more likely to be at risk of lower motor efficiency beginning in childhood. On the other hand, our limited study suggests that lower levels of motor efficiency (G4) generally correspond to less time spent on leisure activities. In addition, parental work commitments (seasonal work or self-employment) are mostly reflected as "lack of time" for outdoor leisure, which in turn reflects in the WFC. Also, the study showed that social network (kinship) plays an important role as children 
can spend their afternoons, weekends, and even holidays more actively with grandparents or other relatives when parents have to work. The results have proved that spending time outdoor PA depends on parental time (mostly provided by mothers) as time "free from economic necessity." At the same time, we would like to point out the problem of mothers' perceived lower sport competence, which was indicated as "not trusting themselves to teach the child a new sport," which was not only a result of the mother's sport history but was more evident also in G4 children.

\section{CONCLUSION}

To conclude, families with children of the highest motor scores (G1) most likely spend afternoons and weekends more actively (trips, hikes, walks) than families with lower motor effective children (G4), who more often practice visits, shopping and rest as leisure time activities. Regarding the work-family conflict (WFC) issue we perceived higher maternal work engagement (double-shift or nightshift work) in families with lower motor efficiency children (G4) and a higher number of "working late fathers" (40\%). In such cases, childcare is not equally divided between the mother and the father, with fathers also more frequently relying on the involvement of relatives (grandmothers, mothers-in-law, sisters and other female relatives) in the care of the children. This confirms the Slovenian example of the transfer of family work (assistance in the care of children) into the sphere of unpaid work (kinship and friendship networks) and paid work (cleaning women and nannies). On the other hand, the study pointed out that children in the most motor effective group more often spent outdoor leisure time with both parents, had active winter and summer holidays and lived in a house with a yard. Additionally, the problem of mothers juggling work and family is clear (Bettio et al., 2014). The problem mirrored in this research is that insufficient and inactive spending of family leisure time is mostly the result of family-work conflict (resulting in "lack of time for outdoor activities") where mothers often ended up in dissatisfaction, fatigue, suffering stress.

We could also point to other important factors that can help solve that problem by providing socio-environmental factors in the local community (kinship networks, safe and suitable areas for children to play independently). Environmental factors (weather, facilities and accessibility for PA) play an important role regarding the active leisure behavior of a family. Because it is hard to change, for example, facilities in a short time without local support, we need to pay attention to other personal and social factors and help underprivileged families (mothers, low income, single parents) to be able to live more active outdoor leisure time. Due to the several positive aspects of active leisure time behavior, the goal of state and local policy should not only be to provide physical and environmental facilities for PA, but also to enhance initiatives promoting and living physically active leisure as incorporated daily "family" behavior. 


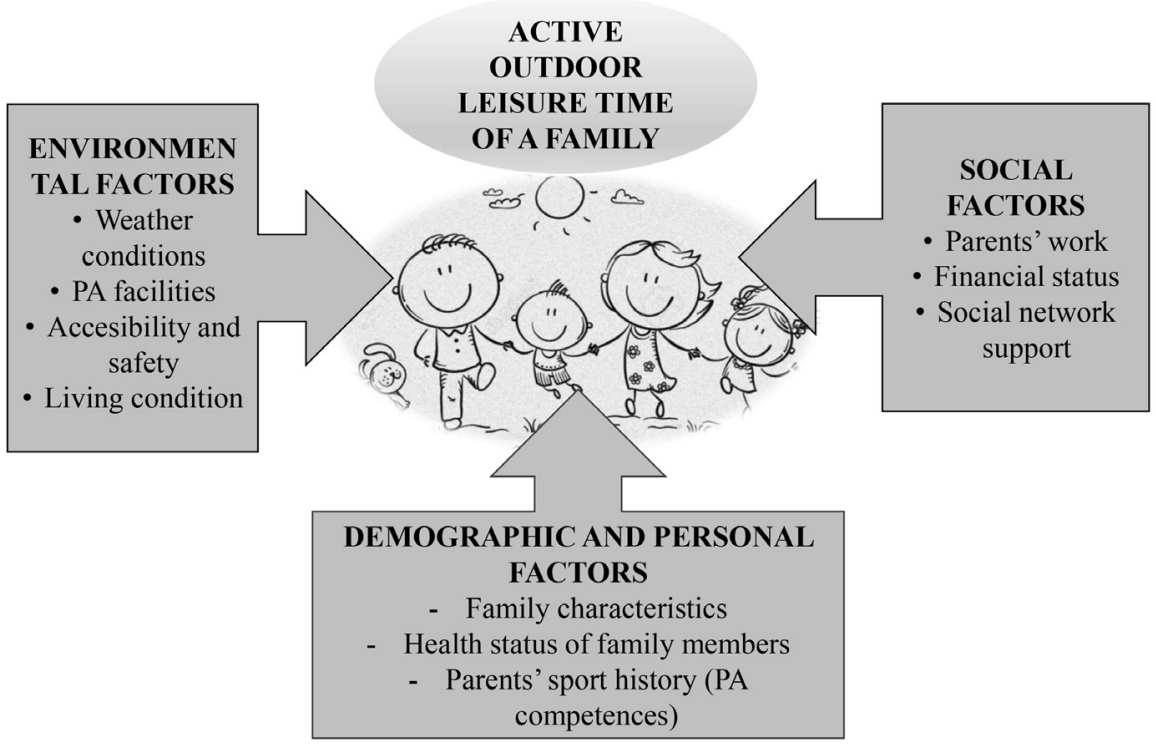

Figure 3: The determinants of family active outdoor leisure time (Pišot, 2018).

\section{Acknowledgement}

Thanks to the colleagues of the Institute for Kinesiology Research at Science and Research Centre, partner institutions for their contribution to the project. We are especially grateful to the parents and children who participated in the study.

\section{REFERENCES}

Andersen, L. B., Mota, J., \& Di Pietro, L. (2016). Update on the global pandemic of physical inactivity. Lancet (London, England), 388(10051), 1255. https://doi. org/10.1016/S0140-6736(16)30960-6.

Arundell, L., Parker, K., Salmon, J., Veitch, J., \& Timperio, A. (2019). Informing behaviour change: what sedentary behaviours do families perform at home and how can they be targeted? International journal of environmental research and public health, 16(22), 4565. https://doi.org/10.3390/ijerph16224565.

Bettio, F., Plantenga, J., \& Smith, M. (Eds.). (2014). Gender and the European labour market. London: Routledge.

Bianchi, S., Sayer, L., Milkie, M., \& Robinson, J. (2012). Housework: who did, does or will do it, and how much does it matter? Social Forces, 91(1), 55-63. https://doi. org/10.1093/sf/sos120. 
Biddle, S. J. H., \& Asare, M. (2011). Physical activity and mental health in children and adolescents: a review of reviews. British Journal of Sports Medicine, 45(11), 886-895. http://dx.doi.org/10.1136/bjsports-2011-090185.

Bourdieu, P. (1986). The forms of capital. In J. G. Richardson (Ed.), Handbook of theory and research for the sociology of education (pp. 241-258). New York: Greenwood Press.

Bouchard, C. (1996). Genetic epidemiology, association, and sib-pair linkage: results from the Québec Family Study. In G. A. Bray, \& D. H. Ryan (Eds.) Molecular and genetic aspects of obesity (pp. 470-481).

Bruininks, R. H., \& Bruininks, B. D. (2005). BOT2: Bruininks-Oseretsky test of motor proficiency. AGS Publishing.

Dietz, W. H. (1998). Health consequences of obesity in youth: childhood predictors of adult disease. Pediatrics, 101(Supp. 2), 518-525.

Dowda, M., Pfeiffer, K. A., Brown, W. H., Mitchell, J. A., Byun, W., \& Pate, R. R. (2011). Parental and environmental correlates of physical activity of children attending preschool. Archives of Pediatrics \& Adolescent Medicine, 165(10), 939-944. https://doi.org/10.1001/archpediatrics.2011.84.

Gordon-Larsen, P., McMurray, R. G., \& Popkin, B. M. (2000). Determinants of adolescent physical activity and inactivity patterns. Pediatrics, 105(6), e83-e83. https:// doi.org/10.1542/peds.105.6.e83.

Janssen, I., \& LeBlanc, A. G. (2010). Systematic review of the health benefits of physical activity and fitness in school-aged children and youth. International Journal of Behavioural Nutrition and Physical Activity, 7(1), 40. https://doi.org/10.1186/14795868-7-40.

Kamin, T., \& Tivadar, B. (2011). Kapital(i) in zdravje [Capital and health]. Teorija in praksa, 48(4). 1028-1047. Retrieved from http://www.dlib.si/details/URN:NBN:SI:DOCQ0LMSGQI.

Kerr, J., Rosenberg, D., Sallis, J. F., Saelens, B. E., Frank, L. D., \& Conway, T. L. (2006). Active commuting to school: associations with environment and parental concerns. Medicine \& Science in Sports \& Exercise, 38(4), 787-793. https://doi. org/10.1249/01.mss.0000210208.63565.73.

Lewis, S., \& Lewis, J. (Eds.). (1996). The Work-Family Challenge: Rethinking Employment. London: Sage Publications.

Mutrie, N., \& Parfitt, G. (1998). Physical activity and its link with mental, social and moral health in young people. Young and active, 49-68.

OECD (2001). Shaping Structural Change: The Role of Women; Organization for Economic Co-operation and Development. Paris, France.

Owen, N., Salmon, J., Koohsari, M. J., Turrell, G., \& Giles-Corti, B. (2014). Sedentary behaviour and health: mapping environmental and social contexts to underpin chronic disease prevention. British Journal of Sports Medicine, 48(3), 174-177. https://doi.org/10.1136/bjsports-2013-093107.

Pišot, S. (2018). Gibalna/športna aktivnost kot determinanta "zdravega" življenjskega sloga družine in otrokovega telesnega kapitala [Physical Activity as a Determinant of a »Healthy« Family Lifestyle and a Child's Physical (Body) Capital] (Doctoral thesis. University of Ljubljana, Faculty of Social Science). Retrieved from http://dk.fdv.unilj.si/doktorska_dela/pdfs/dr_pisot-sasa.pdf. 
Remery, C., \& Schippers, J. (2019). Work-family conflict in the European Union: the impact of organizational and public facilities. International Journal of Environmental Research and Public Health, 16(22), 4419. https://doi.org/10.3390/ijerph16224419.

Rener, T. (2006). Odraščati v družinah [Growing up in families]. In T. Rener, M. Sedmak, A. Švab \& M. Urek (Eds.) Družine in družinsko življenje v Sloveniji [Families and family life in Slovenia]. 89-126. Koper: Založba Annales.

Rener, T., Humer, Ž., Žakelj, T., Vezovnik, A., \& Švab, A. (2008). Novo očetovstvo v Sloveniji [New fatherhood in Slovenia]. Ljubljana: Fakulteta za družbene vede, Založba FDV.

Sugden, D., \& Henderson, S. (2007). Movement assessment battery for children.

Saelens, B. E., Sallis, J. F., Black, J. B., \& Chen, D. (2003). Neighborhood-based differences in physical activity: an environment scale evaluation. American journal of public health, 93(9), 1552-1558. https://doi.org/10.2105/AJPH.93.9.1552.

Ulrich, D. (2000). Test of gross motor development: second edition. Austin, TX: PROED.

Telama, R., Yang, X., Laakso, L., \& Viikari, J. (1997). Physical activity in childhood and adolescence as predictor of physical activity in young adulthood. American Journal of Preventive Medicine, 13(4), 317-323. https://doi.org/10.1016/S07493797(18)30182-X.

Thompson, A. M., Rehman, L. A., \& Humbert, M. L. (2005). Factors influencing the physically active leisure of children and youth: a qualitative study. Leisure Sciences, 27(5), 421-438. https://doi.org/10.1080/01490400500227324.

Trost, S. G., Sallis, J. F., Pate, R. R., Freedson, P. S., Taylor, W. C. \& Dowda, M. (2003). Evaluating a model of parental influence on youth physical activity. American Journal of Preventive Medicine, 25(4), 277-282. https://doi.org/10.1016/S07493797(03)00217-4. 